OPEN ACCESS

Edited by:

Alexandra F. Santos,

King's College London,

United Kingdom

Reviewed by:

Komei Ito,

Aichi Child Health and Medica

General Center, Japan

R. Sharon Chinthrajah,

Stanford University, United States

*Correspondence:

Hervé Bernard

herve.bernard-inra@cea.fr

†These authors have contributed equally to this work and share first

authorship

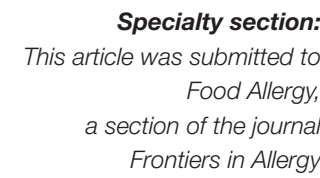

Received: 30 June 2021 Accepted: 07 September 2021 Published: 30 September 2021

Citation:

Bernard H, Hazebrouck S, Gaiani N and Adel-Patient K (2021) Allergen Risk Assessment for Specific Allergy to Small Ruminant's Milk: Development of Sensitive Immunoassays to Detect Goat's and Sheep's Milk

Contaminations in Dairy Food Matrices. Front. Allergy 2:733875.

doi: 10.3389/falgy.2021.733875

\section{Allergen Risk Assessment for Specific Allergy to Small Ruminant's Milk: Development of Sensitive Immunoassays to Detect Goat's and Sheep's Milk Contaminations in Dairy Food Matrices}

\author{
Hervé Bernard ${ }^{* \dagger}$, Stéphane Hazebrouck ${ }^{\dagger}$, Nicolas Gaiani and Karine Adel-Patient \\ Université Paris-Saclay, CEA, INRAE, Département Médicaments et Technologies pour la Santé, Service de Pharmacologie \\ et d'Immunoanalyse, Laboratoire d'Immuno-Allergie Alimentaire, Gif-sur-Yvette, France
}

Despite a high level of sequence identity between cow's, goat's, and sheep's milk (CM, GM, and SM, respectively) proteins, some patients tolerant to CM are allergic to GM and SM. In most cases, this specificity is due to the presence of IgE antibodies that bind only to caprine and ovine caseins. The patients may then develop severe allergic reactions after ingestion of $\mathrm{CM}$ products contaminated with low amounts of GM or SM. We thus aimed to develop an assay able to detect traces of caprine/ovine $\beta$-caseins in different food matrices, irrespective of the presence of the bovine homolog. We produced monoclonal antibodies (mAbs) specific to caprine caseins in mice tolerized to the bovine whole casein then sensitized to the caprine whole casein. In order to develop a two-site immunometric assay, we selected mAbs that could discriminate the caprine $\beta$-casein from its bovine homolog. Characteristics and performances of two tests were determined with various dairy products. Results were analyzed in relation with the lgE-immunoreactivity of the food matrices, thanks to sera from CM, GM/SM allergic patients. Our two-site immunometric assays demonstrated a high sensitivity with a detection limit of $1.6-3.2 \mathrm{ng} / \mathrm{mL}$ of caprine and ovine $\beta$-caseins. The tests were able to detect contaminations of GM in $\mathrm{CM}$ at the ppm level. Heat-treatment, ripening and coagulation processes, usually applied to dairy products that exhibit a very high IgE-immunoreactivity, did not impair the test sensitivity. These quantitative assays could then be useful for the risk assessment of food products potentially contaminated with GM and SM in order to prevent adverse reactions in patients specifically allergic to these milks.

Keywords: milk, allergy, sheep, goat, IgE, $\beta$-casein, ELISA, dairy product

\section{INTRODUCTION}

Milk is one of the foods causing the most frequently an adverse reaction $(1,2)$. Cross-allergenicity between milks from different ruminants are generally observed, thus rendering the use of goat's and sheep's milks (GSM) as substitute of cow's milk (CM) unsafe for patients allergic to CM (3-5). This cross-allergenicity results from 
similar protein compositions and from a high sequence homology between protein components of ruminant milks (68). Nevertheless, despite these structural similarities, allergic reactions to GM or SM can occur in patients tolerant to CM. Since the first report by Wuthrich, this allergy has been regularly observed, mainly in European countries (8-12).

The development of this specific allergy to GSM does not always rely on earlier sensitization to $\mathrm{CM}$ proteins as only $19 \%$ of the GSM-allergic/CM-tolerant patients had suffered from an outgrown CM allergy (12). Moreover, CM-allergic children successfully treated with oral immunotherapy can remain allergic to GSM protein (13-15). Induction of GM-allergy through skin exposure has been also reported $(16,17)$. Allergy to GSM is frequently associated with severe symptoms even after ingestion of low amount of caprine or ovine milk protein in complex food matrices $(11,18-21)$. Beyond the mandatory labeling in EU for foods containing milk protein, the French Agency for Food, Environmental, and Occupational Health and Safety (ANSES) suggested to update the list of allergenic ingredients by adding emerging allergens such as milk from small ruminants (22). Allergen risk management must then assess the unintentional presence of GSM protein in food matrices, including contamination in production lines for dairy products. This assessment thus requires the development of sensitive methods able to detect specifically GSM protein contaminations along the entire food chain process.

Whole Casein (CN) constitutes up to $80 \%$ of the GSM proteins and is present in various dairy products as well as ingredients in processed food matrices. Among the four components of $\mathrm{CN}$, i.e., $\alpha \mathrm{S} 1, \alpha \mathrm{S} 2, \beta$, and $\kappa$-caseins, the $\beta$-casein $(\beta-\mathrm{CN})$ constitutes $\sim 36 \%$ of the whole bovine $\mathrm{CN}$ and up to $50-60 \%$ of the whole $\mathrm{CN}$ from GM and SM, depending on genetic polymorphisms of the small ruminants $(6,7,23)$. The caprine and ovine $\beta$-CN are $99 \%$ identical while the sequence identity between the caprine and bovine $\beta-\mathrm{CN}$ is $92 \%$. Nevertheless, linear IgE-binding epitopes are not necessarily conserved between the caprine and bovine homologs. We previously showed that patients allergic to GSM and tolerant to CM display an IgE response to the caprine and ovine $\beta-\mathrm{CN}$ without significant cross-reactivity to the bovine homolog $(8,24)$. Specific IgE-binding to the caprine $\beta-\mathrm{CN}$ was mostly restricted to two domains, corresponding to amino acid residues 44-88 and 130-178 (25). Among the substitutions occurring between the caprine and bovine $\beta$ - $\mathrm{CN}$ sequences, we further identified the critical role of the substitution T63P in the major non-cross reactive IgE-binding epitope of caprine $\beta-\mathrm{CN}$ (25). We also produced monoclonal antibodies (mAb), which were highly specific to the caprine $\beta-\mathrm{CN}$.

In the present work, we aimed to develop an ELISA for the specific detection of the caprine $\beta-\mathrm{CN}$, irrespective of the presence of $\mathrm{CM}$ proteins in the food matrix. The test was evaluated for its performances (sensitivity and specificity) with various processed dairy foods, in relation to their IgE reactivity. We finally assessed the assay sensitivity for the detection of GM contaminations in CM.

Abbreviations: CN, casein; CM, Cow's Milk; GM, Goat's Milk; SM, Sheep's Milk; GSM, Goat's and Sheep's milks; mAb, monoclonal Antibody; RT, Room Temperature.

\section{MATERIALS AND METHODS}

\section{Anti- $\beta-C N$ mAb Production and Characterization}

Antibodies specific to caprine caseins were produced in mice tolerized to whole bovine $\mathrm{CN}$ through the oral route and then sensitized to whole caprine $\mathrm{CN}$ as previously described (25). In parallel, cross-reactive mAbs to $\beta$-CN were obtained from mice sensitized to bovine $\mathrm{CN}$. All experiments were performed in compliance with the French and European regulations on care and protection of Laboratory Animals (EC Directive 86/609, French Law 2001-486, June 6, 2001) with permission 91-493 of French Veterinary Services. The laboratory animal facility care was approved by the French Veterinary Services and CEA agreement D-91-272-106 from the Veterinary Inspection Department of Essonne (France).

Spleen cells from mice producing the highest levels of IgG1 to $\mathrm{CN}$ were fused with NS1 mouse myeloma cells. The antibodysecreting cells (hybridomas) were screened by analyzing cell supernatants on microtiter plates coated with either bovine or caprine $\beta-\mathrm{CN}$ and using acetylcholinesterase (AChE)-labeled goat anti-mouse antibodies (Jackson ImmunoResearch, Europe Ltd.) as tracer (26).

Selected hybridoma cells were cloned and expanded as ascitic fluids in BALB/c mice. Specificity of the mAb purified from ascitic fluids by protein A affinity chromatography was fully characterized using recombinant, plasmin-derived, and synthetic peptides of bovine and caprine $\beta-\mathrm{CN}$ as previously described for human IgE-binding studies $(24,25)$. Briefly, microtiter plates were coated with either native, recombinant $\beta-\mathrm{CN}$ or peptide at $5 \mu \mathrm{g} / \mathrm{mL}$ in $50 \mathrm{mM}$ carbonate buffer $\mathrm{pH}$ 9.2. Before use, plates were washed and each well was filled with $50 \mu \mathrm{L}$ of purified $\mathrm{mAb}$ over a concentration range from 0.001 to $1 \mu \mathrm{g} / \mathrm{mL}$ in EIA buffer [0.1 M phosphate buffer, $0.1 \%$ bovine serum albumin free of protease and immunoglobulins (Sigma-Aldrich, St-Louis, USA), $0.15 \mathrm{M} \mathrm{NaCl}, 0.01 \%$ sodium azide, $\mathrm{pH} 7.4$ ]. After $2 \mathrm{~h}$ of incubation at room temperature (RT), plates were washed and each well was filled with $50 \mu \mathrm{l}$ of goat anti-mouse AChE conjugate. After $2 \mathrm{~h}$ at RT, wells were washed, filled with 200 $\mu \mathrm{L}$ of Ellman's reagent and the absorbance was measured at $414 \mathrm{~nm}$.

\section{Development of Anti-caprine $\beta-\mathrm{CN}$ Two-Site Immunometric Assays}

Anti-caprine $\beta-\mathrm{CN}$ mAb was immobilized on microtiter plates

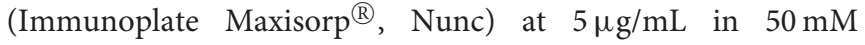
phosphate buffer, $\mathrm{pH} 7.4$, for $24 \mathrm{~h}$ at $4^{\circ} \mathrm{C}$. Plates were then washed and saturated for at least $4 \mathrm{~h}$ at RT using EIA buffer. Diluted samples or internal standards were added (50 $\mu \mathrm{L} /$ well) and incubated for $2 \mathrm{~h}$ at RT under agitation. Wells were washed and $50 \mu \mathrm{L}$ of biotinylated anti- $\beta-\mathrm{CN}$ mAb (antibody:biotin molar ratio 1:20, EZ-link ${ }^{\circledR}$ NHS-PEG4-biotin, Thermo Scientific) were dispatched to each well at a concentration of $100 \mathrm{ng} / \mathrm{mL}$ in EIA buffer. After $2 \mathrm{~h}$ at RT, wells were washed and $50 \mu \mathrm{L}$ of AChE-labeled streptavidin were dispensed for $20 \mathrm{~min}$ at RT. After washing, Ellman's reagent was added and absorbance was measured at $414 \mathrm{~nm}$. Mean blank and SD blank were estimated by measuring eight replicates of signals obtained with EIA buffer. 
The limit of detection (LoD) and of quantification (LoQ) were estimated as mean blank $+3 \times \mathrm{SD}_{\text {blank }}$ and mean blank $+10 \times$ $\mathrm{SD}_{\text {blank }}$, respectively. Precision was characterized by determining intra- and inter-assay coefficients of variation CV. Intra-assay variation was estimated by measuring different concentrations of native caprine $\beta$-CN standards eight times on a single plate (range from 0.156 to $200 \mathrm{ng} / \mathrm{mL}$ ). The working range was then defined as the concentration range for which an intra-assay $\mathrm{CV}$ $<10 \%$ was obtained. The inter-assay CV was calculated with two concentrations of standard inside the working range routinely assayed on different plates. Assay specificity was assessed by measuring signals in the concentration range from 0.1 to $10 \mu \mathrm{g} / \mathrm{mL}$ of purified proteins from CM, GM, and SM $(8,24)$. Cross-reactivity coefficients (in \%) were calculated as the ratio of standard concentration divided by cross-reactant concentration providing the same signal in the two-site immunometric assays.

\section{Preparation of Samples From Processed Dairy Products}

Dairy products classically found in France were purchased from retail outlets. They comprised semi-skimmed UHT milks (Lactel), yogurts (Danone, Vrai), soft goat cheese (Soignon) and semi-soft cheeses (Mini-Babybel cow cheese and Mini-Babybel goat cheese containing $10 \%$ of GM). Raw milks from one cow and one goat were included as control.

Yogurt or cheese $(1 \mathrm{~g})$ were resuspended in $10 \mathrm{~mL}$ of $50 \mathrm{mM}$ ammonium carbonate buffer, $10 \mathrm{mM}$ EDTA, 1\% Octylbeta-Glucoside using DT-20 dispersing tube (IKA ${ }^{\circledR}$ ULTRATURRAX ${ }^{\circledR}$ ). After homogenization, samples were mixed during $1 \mathrm{~h}$ at $4^{\circ} \mathrm{c}$, aliquoted and stored at $-80^{\circ} \mathrm{C}$. Samples were diluted in the ammonium carbonate buffer at $1 \mathrm{mg}$ of protein/ $\mathrm{mL}$ by taking into account the initial protein content of the dairy product.

\section{IgE-Binding Capacity as Determined by Reverse East Inhibition}

IgE binding capacity was performed in a reverse EAST inhibition assay using sera from retrospective studies $(24,25)$. One serum from CM-allergic patient (\#116) and two sera from GMallergic/CM tolerant (\#64, \#183) patients were selected for this analysis. Anaphylactic shock was reported for the CM-allergic patient after ingestion of bovine milk product. His serum displayed an IgE response above $50 \mathrm{IU} / \mathrm{mL}$ for both bovine and caprine $\beta$-CNs. GM-allergic/CM tolerant (\#64, \#183) patients suffered from angio-oedema or asthma, urticaria and rhinoconjunctivitis, respectively, after ingesting goat cheese. Specific IgE levels were 10 and $50 \mathrm{IU} / \mathrm{mL}$ for caprine $\beta-\mathrm{CN}$ and negative or below $2 \mathrm{IU} / \mathrm{mL}$ for bovine $\beta-\mathrm{CN}$, respectively.

For reverse EAST inhibition, plates were coated with antihuman IgE mAb LE27. Fifty $\mu \mathrm{L} /$ well of serum from each patient at appropriate dilutions (1:100 to 1:400) were incubated overnight at $4^{\circ} \mathrm{C}$. After washing, $25 \mu \mathrm{L}$ of inhibitors (i.e., increasing concentrations of proteins from dairy samples) and $25 \mu \mathrm{L}$ of AChE-labeled caprine $\beta$-CN were mixed and incubated for $4 \mathrm{~h}$ at RT. Results were expressed as B/B0, where B0 and $\mathrm{B}$ represent the amount of labeled caprine $\beta-\mathrm{CN}$ bound to immobilized IgE antibodies in the absence or presence of a known concentration of inhibitor, respectively.

\section{Spiking Experiments}

One $\mathrm{mL}$ of raw $\mathrm{GM}$ was diluted in $10 \mathrm{~mL}$ of raw $\mathrm{CM}$ corresponding to a contamination of 100,000 ppm. Ten-fold serial dilutions ( $1 \mathrm{in} 10 \mathrm{~mL}$ ) were then performed in CM to finally obtain a solution of $10 \mathrm{ppm}$ of GM in CM. This last dilution was used to generate a CM contaminated at 2 and $1 \mathrm{ppm}$ of GM. Spiking experiment was similarly performed with UHT CM spiked with UHT GM.

For two-site immunometric assays, the samples were two-fold diluted in EIA buffer with $0.1 \%$ Tween ${ }^{\circledR} 20$ Detergent before analysis. Mean blank and SD blank were estimated by measuring replicates of signals obtained with EIA buffer, $0.1 \%$ Tween ${ }^{\circledR}$ 20. The signal-to-noise ratio was evaluated in comparison with CM milk.

\section{RESULTS}

\section{Specificity of Anti- $\beta-C N$ mAb}

Four hybridomas producing mAb specific to the caprine $\beta$-CN and not reacting to the bovine homolog were selected, cloned, expanded and purified. The $\mathrm{mAb} \mathrm{CC} 1$ and $\mathrm{CC} 7 \mathrm{~B}$ recognized the C-terminal part (f108-207) of the caprine $\beta$-CN (Table 1). The sole substitution of the Lys residue at position 132 of the recombinant caprine $\beta-\mathrm{CN}$ by the Asn residue found in the bovine counterpart abolished their binding. The mAb SCB1 and SCB4 recognized the N-terminal fragment $\mathrm{f}(29-107)$ of $\beta-\mathrm{CN}$. These mAbs were able to bind to a synthetic peptide covering the domain 49-79 but not to the caprine $\beta$ - $\mathrm{CN}$ carrying the sole substitution of Thr residue at position 63 by the corresponding bovine Pro residue.

Two cross-reactive $\mathrm{mAb}, \mathrm{CC} 11$ and VB1, were produced from mice sensitized to the bovine $\mathrm{CN}$. The $\mathrm{mAb} \mathrm{CC} 1$ bound to the fragments (f106-209) and (f108-207) covering the C-terminal part of the bovine and caprine $\beta-\mathrm{CN}$, respectively. The $\mathrm{mAb} \mathrm{VB} 1$ recognized the fragment (f29-105) of the bovine $\beta-\mathrm{CN}$ and the peptides (f29-107) and (f80-107) from the caprine $\beta-\mathrm{CN}$.

\section{Development of Two-Site Immunometric Assays}

A matched antibody pairs test was performed using each of the non-cross reactive $\mathrm{mAb}$ SCB1/SCB4 or CC1/CC7 as immobilized $\mathrm{mAb}$ to capture caprine $\beta-\mathrm{CN}$. For the detection, in addition to a mAb specific to the caprine $\beta-\mathrm{CN}$, we also tested cross-reactive $\mathrm{mAb}$, i.e., $\mathrm{mAb} \mathrm{CC} 11$ and VB1 that recognized both caprine and bovine $\beta$-CN.

As shown in Figure 1, the combination of the non-cross reactive $\mathrm{mAb} \mathrm{CC} 7$ (or $\mathrm{CC} 1$ ) for the capture and $\mathrm{mAb} \mathrm{SCB} 1$ (or SCB4) for the detection did not provide a highly sensitive assay of the caprine $\beta-\mathrm{CN}$ with a LoD above $10 \mathrm{ng} / \mathrm{mL}$. Same characteristics using SCB1 for the capture and $\mathrm{CC} 7$ for the detection were obtained (data not shown). A higher level of sensitivity (LoD $<5 \mathrm{ng} / \mathrm{mL}$ ) was obtained by using mAb SCB1 for the capture and the cross-reactive $\mathrm{mAb}$ VB1 or CC11 for the detection. No significant signal with the bovine $\beta-\mathrm{CN}$ was 
TABLE 1 | Specificity of anti- $\beta$-CN monoclonal antibodies.

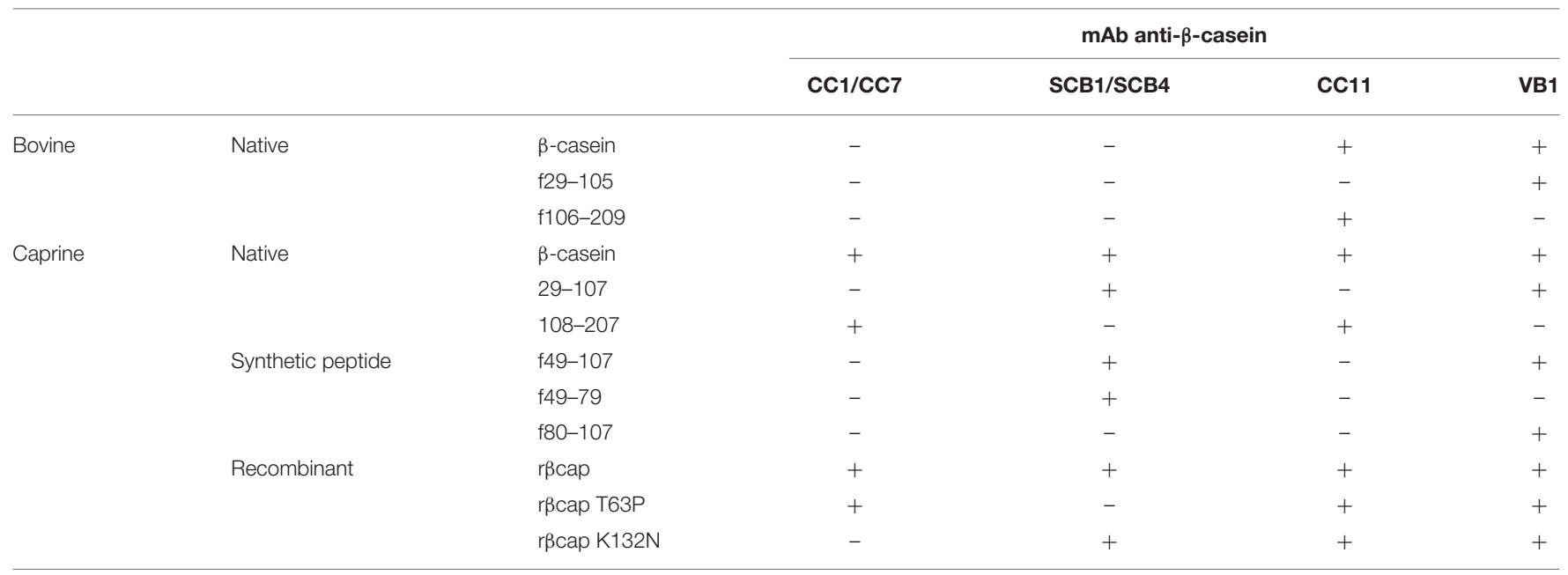

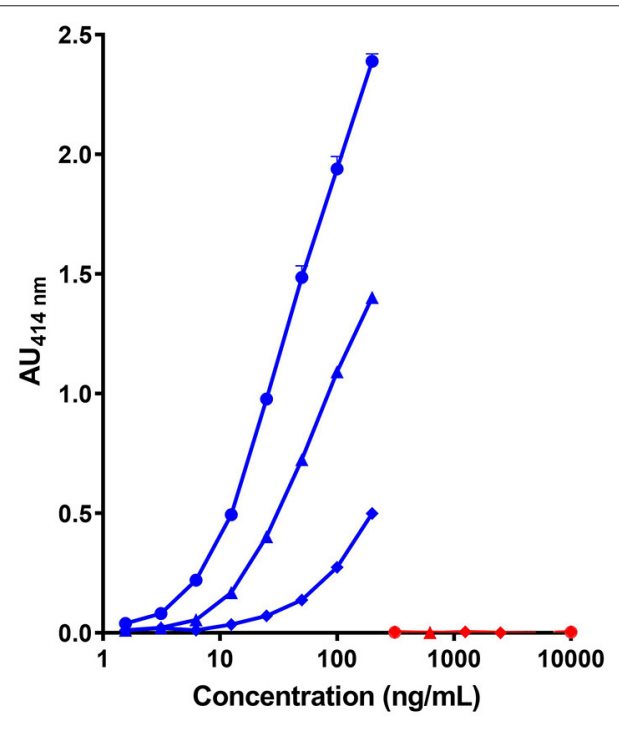

FIGURE 1 | Detection of caprine (blue symbols) and bovine $\beta$-CN (red symbols) using three pairs of immobilized/biotinylated mAbs, (•)SCB1/CC11, ( $\mathbf{\Delta}$ SCB1/NB1, and ( $)$ CC7/SCB1 in corresponding two-site immunoassays

observed with any of the tested pairs of $\mathrm{mAb}$, even at a protein concentration up to $10 \mu \mathrm{g} / \mathrm{mL}$.

\section{Characteristics of the Anti-caprine $\beta-C N$ ELISA}

Development of two-site immunometric assays was then pursued only with SCB1 as the capture mAb and VB1 or CC11 as the detection $\mathrm{mAb}$. The two assays displayed very similar sensitivity and specificity (Table 2). A LoD between 1.6 and $3.2 \mathrm{ng} / \mathrm{mL}$ was achieved with purified caprine $\beta-\mathrm{CN}$ as standard reference. The other caprine caseins showed a cross-reactivity coefficient below $0.04 \%$ at a concentration up to $10 \mu \mathrm{g} / \mathrm{mL}$. The signal above LoD obtained with the caprine $\beta$-lactoglobulin (BLG) was probably due to $\beta$-CN contamination in the purified BLG rather than

TABLE 2 | Characteristics of the two-site immunometric assays for caprine $\beta$-CN detection.

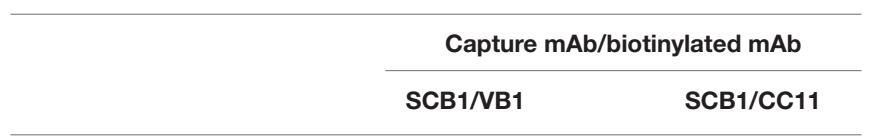

\section{Caprine $\beta$-casein}

LoD (Mean of all blank

values $+3 \times$ Standard

deviation) $(\mathrm{ng} / \mathrm{mL})$

LoQ (Mean of all blank

values $+10 \times$ Standard

deviation) $(\mathrm{ng} / \mathrm{mL})$

Working range $(\mathrm{ng} / \mathrm{mL})^{*}$

Cross-reactivity $(\%)^{\star \star}$

\section{Caprine***}

as1-casein

as2-casein

$\kappa$-casein

$\beta$-Lactoglobulin

Bovine $^{\star \star *}$

$\beta$-casein

as1-casein

as2-casein

$\kappa$-casein

$\beta$-Lactoglobulin

Ovine ${ }^{\star \star \star}$

$\beta$-casein
3.2

1.6

4

3.2

6-200

4-200

$<0.032$

$<0.016$

$<0.032$

$<0.032$

$<0.016$

0.1

$<0.016$

0.15

$<0.032$

$<0.016$

$<0.032$

$<0.032$

$<0.032$

$<0.032$

$<0.016$

$<0.016$

$<0.016$

$<0.016$

98

102
*The working range was defined as the range with an intra-assay $\mathrm{CV}<10 \%$.

** The cross-reactivity coefficients were determined as the ratio of caprine $\beta$-casein concentration divided by cross-reactant concentration providing the same signal in the two-site immunometric assay. $<0.032$ or <0.016: no significant signal was detected at the highest concentration of $10 \mu \mathrm{g} / \mathrm{mL}$.

${ }^{* * *}$ Milk proteins were purified as previously described (8).

to an actual cross-reactivity between caprine BLG and $\beta-\mathrm{CN}$. Moreover, none of the tested CM proteins, including bovine $\beta-\mathrm{CN}$ and $\mathrm{BLG}$, gave a significant signal at a concentration up to $10 \mu \mathrm{g} / \mathrm{mL}$. In contrast, a cross-reactivity close to $100 \%$ 


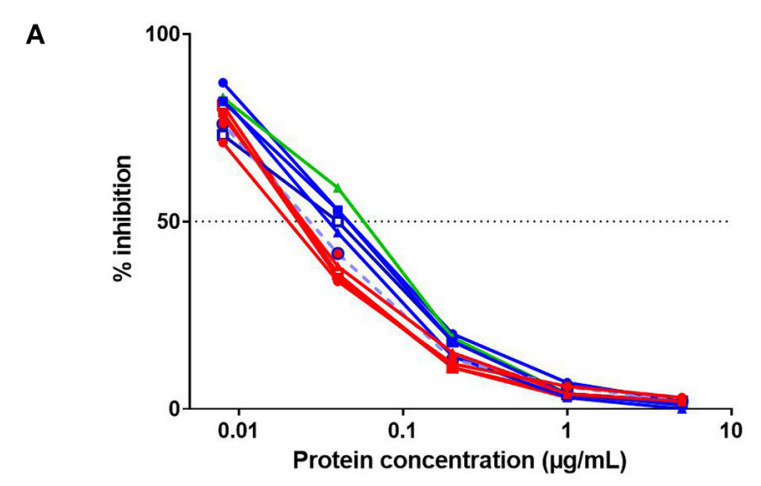

B

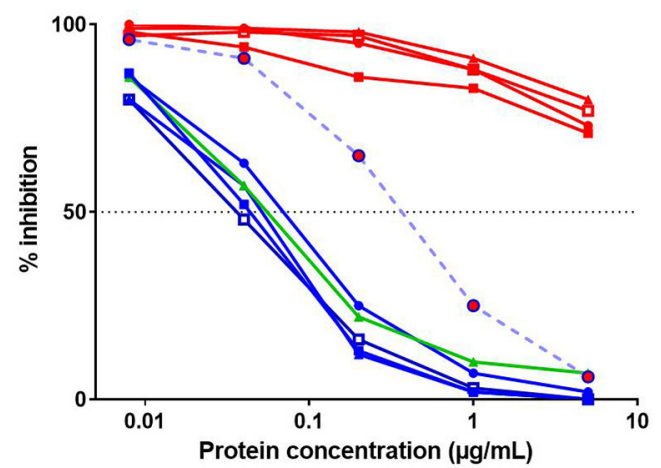

C

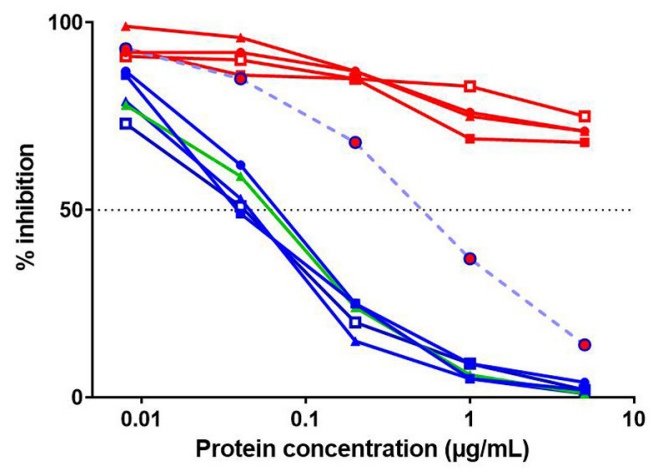

Protein concentration $(\mu \mathrm{g} / \mathrm{mL})$

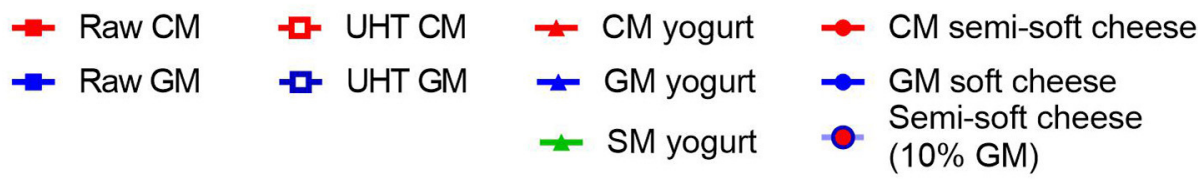

FIGURE 2 | Competitive inhibition of IgE-binding (reverse EAST inhibition) to caprine $\beta$-CN by increasing concentrations of various dairy products (see legends) by using sera from $\mathrm{CM}$-allergic patient $\mathbf{( A )}$ and from $\mathrm{GM}$-allergic/CM-tolerant patients $(\mathbf{B}, \mathbf{C})$.

was observed between caprine and ovine $\beta$-CN in the two immunometric assays.

\section{IgE-Binding Capacity of Processed Dairy Products}

We first evaluated the IgE-reactivity of $\beta-\mathrm{CN}$ present in protein extracts from different dairy products, including raw and heattreated milk, yogurts, and cheeses (Figure 2). Using a serum from a CM-allergic patient, all CM products exhibited comparable capacities to inhibit the IgE-binding to the caprine $\beta-\mathrm{CN}$, thus illustrating the expected $\operatorname{IgE}$ cross-reactivity between bovine and caprine $\mathrm{CN}$ (Figure 2A). These results also indicated that the different processes, i.e., heat treatment, fermentation and cheese production, did not alter significantly the bovine $\beta$-CN immunoreactivity. Similarly, no significant difference was observed between $\beta$-CN immunoreactivities from the different products containing GSM protein although GSM products displayed a slightly lower inhibitory capacity than the CM products.

Conversely, a very low IgE cross-reactivity between CM and GSM products was observed when using sera from two GMallergic/CM-tolerant patients (Figures 2B,C). The processed GSM products displayed a capacity to inhibit IgE-binding to the caprine $\beta$-CN very similar to that of raw GM. In contrast, CM products failed to inhibit more than $30 \%$ of the IgE-binding at the highest tested protein concentration. The cheese containing $90 \%$ of CM and $10 \%$ of GM exhibited a half-maximal inhibitory concentration about 10-fold higher than that of the cheese containing only GM.

\section{Detection of Caprine $\beta-\mathrm{CN}$ in Processed Dairy Foods}

We then analyzed the processed dairy products using the twosite immunoassays with the matched $\mathrm{mAb}$ pair SCB1/VB1 or SCB1/CC11 (Figure 3). No significant signal was observed in the 

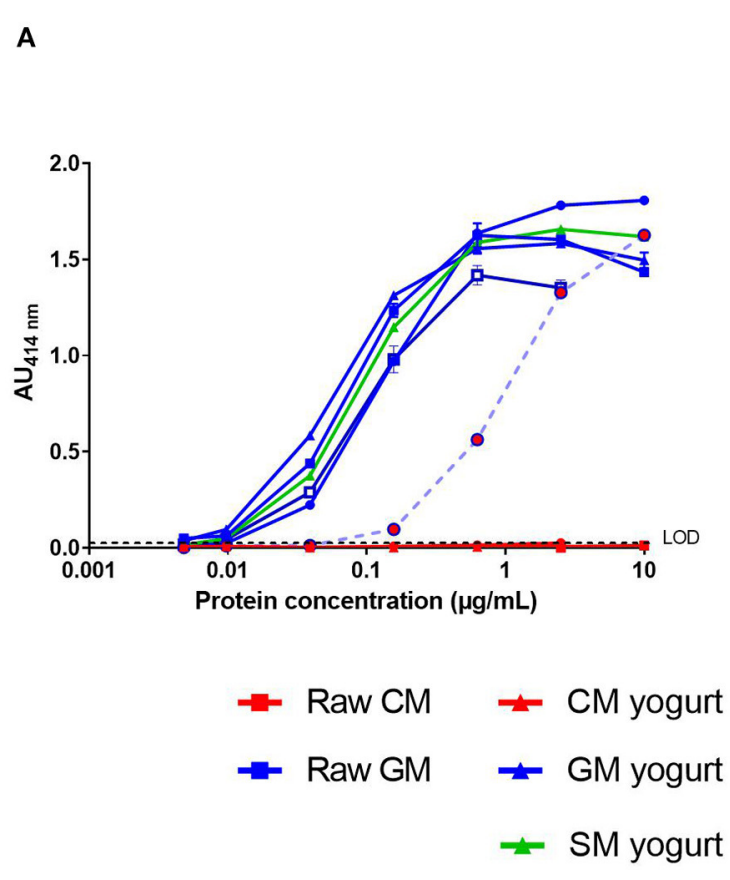

B
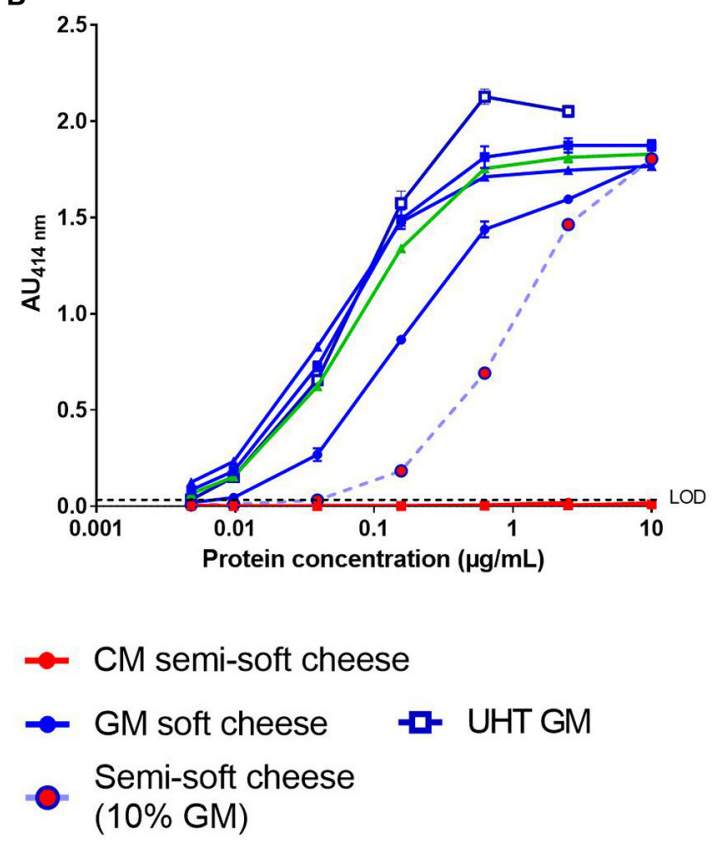

FIGURE 3 | Detection of caprine $\beta$-CN in various dairy products (see legends) using SCB1/NB1 (A) or SCB1/CC11 (B) two-site immunoassay. LoD, Limit of Detection.

$\mathrm{CM}$ products, regardless of the mAb pair tested (Figures $\mathbf{3 A}, \mathbf{B}$ ). For both assays, the dose-response curves obtained with GSM products were parallel to that observed with raw GM. The LoD of caprine $\beta-\mathrm{CN}$ in GSM products was around $10 \mathrm{ng} / \mathrm{mL}$ for the SCB1/VB1 pair (Figure 3A). A lower LoD of $5 \mathrm{ng} / \mathrm{mL}$ was reached with the $\mathrm{mAb} S \mathrm{SB} 1 / \mathrm{CC} 11$ pair except for the GM soft cheese (Figure 3B). Both assays detected a level of caprine $\beta-\mathrm{CN}$ in the GM semi-soft cheese corresponding to a GM concentration of around $10 \%$. Furthermore, dose-response curves from goat's and sheep's yogurts overlapped.

\section{Detection of GM Contamination in CM}

For both two-site immunoassays, signals measured with raw $\mathrm{CM}$ were below the LoD (Figures 4A,C) while those measured with heat-treated $\mathrm{CM}$ were slightly above the LoD, in particular with the mAb pair SCB1/CC11 (Figures 4B,D). Whatever, caprine $\beta$ $\mathrm{CN}$ was significantly detected in raw CM spiked with raw GM at a contamination level as low as $1 \mathrm{ppm}$, with a signal-to-noise ratio of at least 3:1. For UHT milk, signals measured for a GM contamination of $1 \mathrm{ppm}$ were almost two-fold higher than those measured with pure CM.

\section{DISCUSSION}

Detection of allergen contaminations in food matrices is one of the keystones of allergen risk management. Unintentional cross-contamination with milks from different ruminants may in particular arise during the processing of dairy products. Various methods including biochemical, immunochemical and molecular biology techniques have been developed to discriminate between milk proteins from different ruminants (27-30). These methods are applied mostly for the detection of milk adulteration, i.e., the fraudulent incorporation of CM in GSM for economic reasons. Although some of these methods could also detect GSM presence in CM, they do not offer a sensitivity sufficient to detect trace contaminations. In this regard, two-site immunoassay remains the method of choice for its specificity, sensitivity and feasibility. However, production of antibodies specific to a milk protein from a ruminant without any cross-reactivity to homologs from other ruminants is particularly challenging because of the high sequence identity among ruminants' milk proteins. One approach to obtain specific antibodies relies on the immunization of animals with peptides covering domains displaying the highest structural differences between the milk proteins of interest (30). However, antibodies obtained through this approach often exhibit a lower affinity to the native full protein than to the targeted peptide, thus limiting the sensitivity and rendering the assay inadequate for the detection of trace amount of protein contamination $(31,32)$. We thus applied another strategy by inducing tolerance to bovine $\mathrm{CN}$ in mice before sensitizing them to the caprine $\mathrm{CN}$ in order to limit the production of cross-reactive antibodies. This strategy was inspired by a study reporting that $\mathrm{CM}$-allergic patients could remain allergic to $\mathrm{GM}$ after a successful desensitization to CM (14). Using this approach, we succeeded to obtain different mAbs specific to caprine $\alpha \mathrm{S} 1$-, $\beta-$, or $\kappa-\mathrm{CN}$.

We then chose to target specifically the $\beta-\mathrm{CN}$ for its high IgE immunoreactivity and because it is generally the most abundant CN in $\operatorname{GSM}(23,33)$. Moreover, this casein is only slightly hydrolyzed in cheese by chymosin and/or 
A

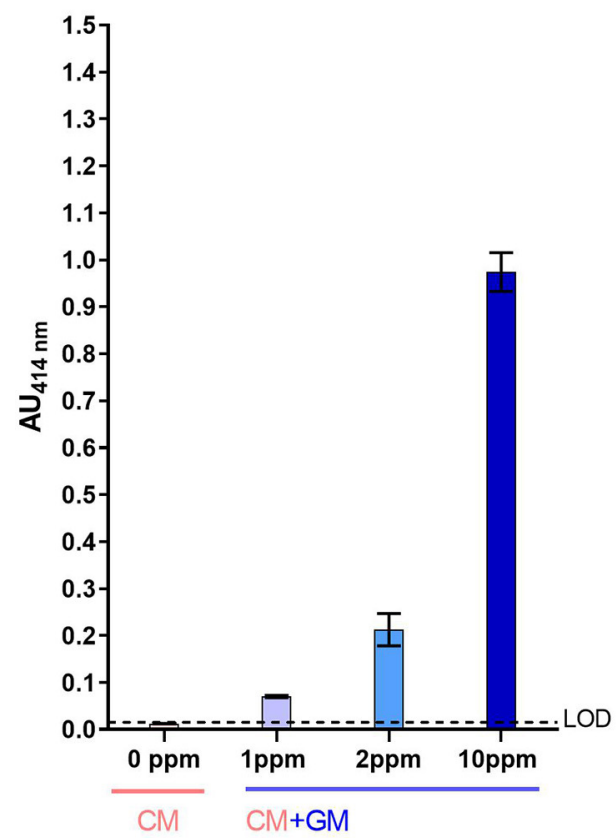

C

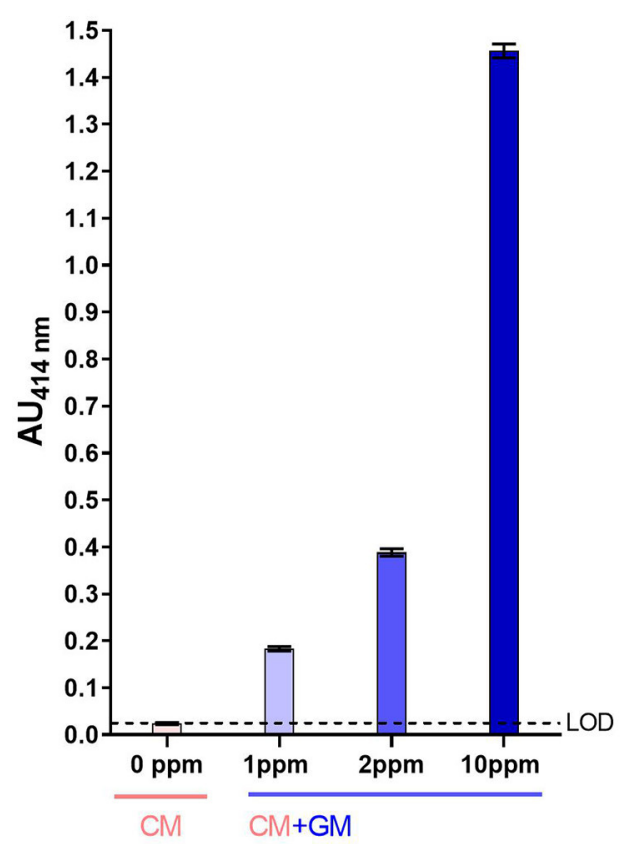

B

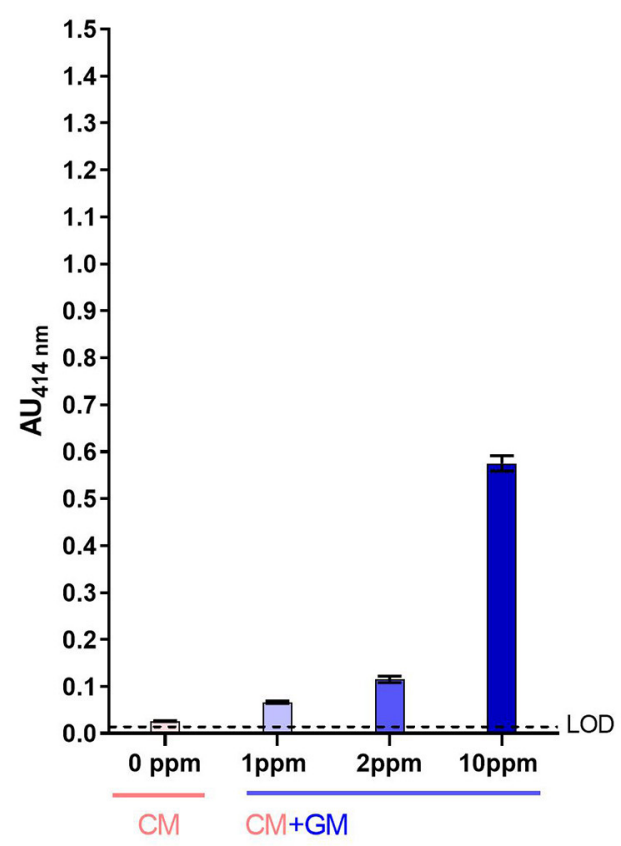

D

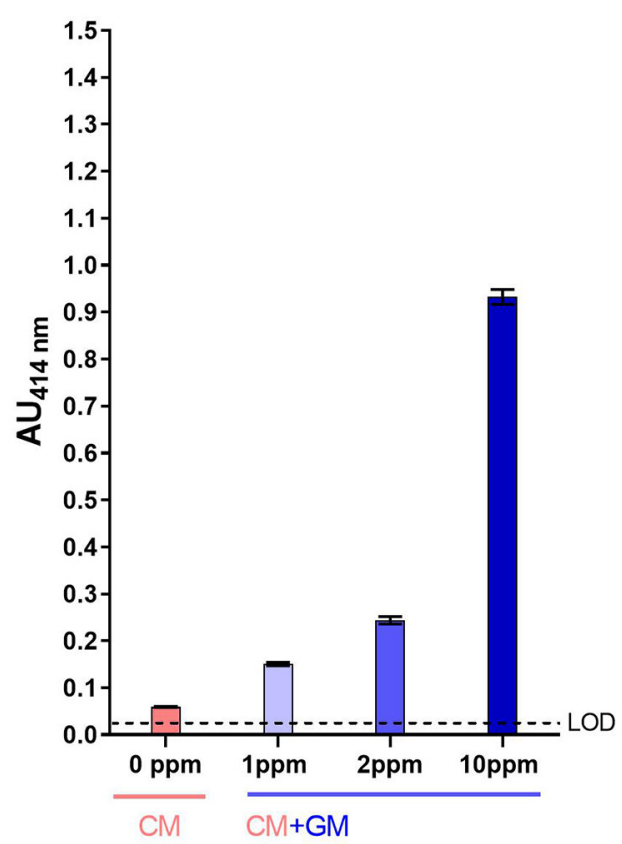

FIGURE 4 | Detection of caprine $\beta-C N$ in CM spiked with GM using SCB1/NB1 (A,B) and SCB1/CC11 (C,D) two-site immunoassays. Analysis was performed using raw milk (A,C) and UHT milk (B,D). LoD, Limit of Detection.

pepsin (34-36). In addition, $\beta-\mathrm{CN}$ is generally considered to possess no or little secondary structures and then to be heatstable (37-39). This property was confirmed in the present study since the IgE-binding capacity of $\beta$-CN was not affected in the different processed milk products. Indeed, the IgEbinding epitopes of caprine $\beta-\mathrm{CN}$ were maintained during pasteurization and UHT processing as previously observed for CM and GM caseins (40-43). Moreover, the IgE-binding capacity of caprine $\beta$-CN was maintained in dairy products even after enzymatic processes that occur during ripening, in accordance with the allergenicity of $\mathrm{CM}$ and/or GM cheeses $(9,10,44)$. 
The mAb recognizing the caprine $\beta-\mathrm{CN}$, with or without cross-reactivity with the bovine $\beta-\mathrm{CN}$, were directed against four different domains. Although the pair of non-cross-reactive $\mathrm{mAb}$ CC7 and SCB1 was functional to detect caprine $\beta-\mathrm{CN}$, a higher sensitivity without decrease of specificity was obtained by using for detection a cross-reactive $\mathrm{mAb}$, i.e., $\mathrm{mAb} \mathrm{VB1}$ or $\mathrm{CC} 11$. Interestingly, the $\mathrm{mAbs} \mathrm{SCB} 1 / \mathrm{VB} 1$ pair recognized the short domain 49-107 of $\beta$-CN, which encompasses major IgE-binding epitopes (24). As observed for the IgE-reactivity, heat-treatment, yogurt fermentation, casein coagulation, and cheese ripening generally did not affect the detection of caprine $\beta$ - $\mathrm{CN}$ by our twosite immunometric assays. Thus, although protein aggregation during heat treatment could reduce the epitope accessibility and thereby the $\beta-\mathrm{CN}$ detection, the assay was still able to detect a contamination of $2 \mu \mathrm{L}$ of UHT GM diluted in $1 \mathrm{~L}$ of UHT CM. Of note, detection of $\beta$-CN was partially altered in soft cheese for the mAbs SCB1/CC11 pair. Soft cheese processing could probably generate limited proteolysis and breakdown products of caprine $\beta$-CN not recognized by the SCB1/CC11 pair but still detectable by the SCB1/VB1 pair. This result suggests that the domain 49-107, recognized by the pair SCB1/VB1, is more resistant to chymosin and pepsin proteolysis during renneting than the larger fragment recognized by the pair SCB1/CC11. This assay could then allow the detection of caprine $\beta-\mathrm{CN}$ and derived peptides in multiple dairy products in spite of proteolytic processes including possible hydrolysis by plasmin $(35,45)$.

Considering a LoD of $10 \mathrm{ng} / \mathrm{mL}$ of caprine $\beta-\mathrm{CN}$ in dairy products resuspended with a mass-to-volume ratio of 1:10, a LoD of $0.1 \mathrm{ppm}$ (100 ng of $\beta$-CN in $1 \mathrm{~g}$ of dairy matrix) was reached without significant interference from bovine milk. The LoD of our immunoassays was then at least as sensitive as the ones developed to assess CM protein contamination, in particular to detect bovine casein $(46,47)$. Unfortunately, eliciting doses of GSM based on clinical data are still missing, probably because of the low prevalence of GSM allergy without CM allergy. Allergic reactions have been described after ingestion of limited amounts (few grams) but without clear quantitative eliciting doses (8). Two cases of allergic reaction were observed due to the ingestion of foods contaminated with GM protein along the food chain (8). Moreover, 15 allergic patients treated with cow's milk oral immunotherapy reacted to cumulative doses varying between 5 and $100 \mathrm{~g}$ of GM or SM cheese during open food challenge (14). Clinical studies are still then required to establish threshold doses for GSM allergy. Nevertheless, assuming similar threshold doses

\section{REFERENCES}

1. Rona RJ, Keil T, Summers C, Gislason D, Zuidmeer L, Sodergren E, et al. The prevalence of food allergy: a meta-analysis. J Allergy Clin Immunol. (2007) 120:638-46. doi: 10.1016/j.jaci.2007.05. 026

2. Flom JD, Sicherer SH. Epidemiology of cow's milk allergy. Nutrients. (2019) 11:1051. doi: 10.3390/nu11051051

3. Restani P, Gaiaschi A, Plebani A, Beretta B, Cavagni G, Fiocchi A, et al. Cross-reactivity between milk proteins from different animal species. Clin Exp Allergy J Br Soc Allergy Clin Immunol. (1999) 29:9971004. doi: 10.1046/j.1365-2222.1999.00563.x for CM and GSM allergies, the present tests could provide a high enough sensitivity to warrant the safety of food products for allergic patients.

\section{CONCLUSION}

In the present work, we developed two immunoassays allowing the detection of caprine $\beta-\mathrm{CN}$ with a LoD lower than $4 \mathrm{ng} / \mathrm{mL}$ and without any cross-reactivity with the bovine $\beta$ $\mathrm{CN}$. These in-house immunoassays were both able to detect GM contamination in CM at a level as low as 1-2 ppm. They are also effective for the detection of caprine $\beta$-CN in dairy products whatever the processes used, i.e., pasteurization, UHT treatment, fermentation, casein coagulation, and cheese ripening, in line with IgE-immunoreactivity of the tested products.

\section{DATA AVAILABILITY STATEMENT}

The raw data supporting the conclusions of this article will be made available by the authors, without undue reservation.

\section{ETHICS STATEMENT}

The animal study was reviewed and approved by the French Veterinary Services and CEA agreement D-91-272-106 from the Veterinary Inspection Department of Essonne (France). All experiments were performed in compliance with the French and European regulations on care and protection of Laboratory Animals (EC Directive 86/609, French Law 2001-486, June 6, 2001) with permission 91-493 of French Veterinary Services.

\section{AUTHOR CONTRIBUTIONS}

$\mathrm{HB}$ and $\mathrm{SH}$ designed the whole study, performed the experiments, interpreted the data, and wrote the manuscript. NG help to perform some experiments. KA-P managed the study and critically revised the manuscript. All authors approved the submitted version.

\section{FUNDING}

This study obtained a financial support from INRAE (Institut National de Recherche pour l'Agriculture, l'Alimentation et l'Environnement).
4. Host A, Halken S. Cow's milk allergy: where have we come from and where are we going? Endocr Metab Immune Disord Drug Targets. (2014) 14:2-8. doi: 10.2174/18715303146661401211 42900

5. Järvinen KM, Chatchatee P. Mammalian milk allergy: clinical suspicion, cross-reactivities and diagnosis. Curr Opin Allergy Clin Immunol. (2009) 9:251-8. doi: 10.1097/ACI.0b013e32832b3f33

6. Roy D, Ye A, Moughan PJ, Singh H. Composition, structure, and digestive dynamics of milk from different species-a review. Front Nutr. (2020) 7:577759. doi: 10.3389/fnut.2020.577759

7. Balthazar CF, Pimentel TC, Ferrão LL, Almada CN, Santillo A, Albenzio $\mathrm{M}$, et al. Sheep milk: physicochemical characteristics and relevance for 
functional food development. Compr Rev Food Sci Food Saf. (2017) 16:24762. doi: 10.1111/1541-4337.12250

8. Ah-Leung S, Bernard H, Bidat E, Paty E, Rancé F, Scheinmann $\mathrm{P}$, et al. Allergy to goat and sheep milk without allergy to cow's milk. Allergy. (2006) 61:1358-65. doi: 10.1111/j.1398-9995.2006. 01193.x

9. Wüthrich B, Johansson SG. Allergy to cheese produced from sheep's and goat's milk but not to cheese produced from cow's milk. $J$ Allergy Clin Immunol. (1995) 96:270-3. doi: 10.1016/S0091-6749(95) 70021-8

10. Bencharitiwong R, Giavi S, Vereda A, Ibáñez MD, Järvinen KM, Papadopoulos $\mathrm{NG}$, et al. Heating does not decrease immunogenicity of goat's and ewe's milk. J Allergy Clin Immunol Pract. (2013) 1:418-21. doi: 10.1016/j.jaip.2013. 04.012

11. Mulé P, Gabrielli S, Upton J, Em A, Ben-Shoshan M. Anaphylaxis to goat/sheep's milk in a 4-year-old boy tolerant to cow's milk. BMJ Case Rep. (2020) 13:e232844 doi: 10.1136/bcr-2019-232844

12. Bidat E. L'allergie au lait de chèvre ou de brebis. Rev Fr Allergol. (2010) 1670:91. doi: 10.1016/j.reval.2010.01.018

13. Alonso-Lebrero E, Fuentes V, Zapatero L, Pérez-Bustamante S, Pineda F, Martinez-Molero MI. Goat's milk allergies in children following specific oral tolerance induction to cow's milk. Allergol Immunopathol (Madr). (2008) 36:180-1. doi: 10.1016/S0301-0546(08)72544-8

14. Rodríguez del Río P, Sánchez-García S, Escudero C, Pastor-Vargas C, Sánchez Hernández JJ, Pérez-Rangel I, et al. Allergy to goat's and sheep's milk in a population of cow's milk-allergic children treated with oral immunotherapy. Pediatr Allergy Immunol. (2012) 23:12832. doi: $10.1111 /$ j.1399-3038.2012.01284.x

15. Martorell Aragonés A, Martorell Calatayud C, Pineda F, Félix Toledo R, Cerdá Mir JC, de las Marinas MD. Persistence of allergy to goat's milk after specific induction of tolerance to cow's milk. J Investig Allergol Clin Immunol. (2012) 22:301-2. Available online at: http://www.jiaci.org/issues/vol22issue4/ vol22issue04-16.htm (accessed September 14, 2021).

16. Voskamp AL, Zubrinich CM, Abramovitch JB, Rolland JM, O'Hehir RE. Goat's cheese anaphylaxis after cutaneous sensitization by moisturizer that contained goat's milk. J Allergy Clin Immunol Pract. (2014) 2:62930. doi: 10.1016/j.jaip.2014.04.012

17. Anantharajah A, Randall KL. Goat's milk allergy in a family following household sensitization to goat's milk soap. Asia Pac Allergy. (2021) 11:e13. doi: 10.5415/apallergy.2021.11.e13

18. Alvarez MJ, Lombardero M. IgE-mediated anaphylaxis to sheep's and goat's milk. Allergy. (2002) 57:1091-2. doi: 10.1034/j.1398-9995.2002.23836_13.x

19. Bidat E, Rancé F, Baranès T, Goulamhoussen S. Goat's and sheep's milk allergies in children in the absence of cow's milk allergy. $J$ Allergy Clin Immunol. (2003) 111:S104. doi: 10.1016/S0091-6749(03)8 0296-8

20. Martins P, Borrego LM, Pires G, Pinto PL, Afonso AR, Rosado-Pinto J. Sheep and goat's milk allergy-a case study. Allergy. (2005) 60:12930. doi: 10.1111/j.1398-9995.2004.00498.x

21. Goh SH, Chong KW, Loh W, Goh AEN. Goat's milk anaphylaxis in a cow's milk tolerant child. Asia Pac Allergy. (2019) 9:e34. doi: 10.5415/apallergy.2019.9.e34

22. ANSES. Food Allergies: Improve Information to Prevent Risks. Available online at: https://www.anses.fr/en/content/food-allergies-improve-informationprevent-risks (accessed September 14, 2021).

23. Marletta D, Criscione A, Bordonaro S, Guastella A Maria, D'Urso G. Casein polymorphism in goat's milk. Lait. (2007) 87:491-504. doi: 10.1051/lait:2007034

24. Bernard H, Ah-Leung S, Tilleul S, Drumare M-F, Paty E, Bidat E, et al. Specificity of IgE antibodies from patients allergic to goat's milk and tolerant to cow's milk determined with plasmin-derived peptides of bovine and caprine $\beta$-caseins. Mol Nutr Food Res. (2012) 56:1532-40. doi: 10.1002/mnfr.2012 00229

25. Hazebrouck S, Ah-Leung S, Bidat E, Paty E, Drumare M-F, Tilleul S, et al. Goat's milk allergy without cow's milk allergy: suppression of non-cross - reactive epitopes on caprine $\beta$-casein. Clin Exp Allergy J Br Soc Allergy Clin Immunol. (2014) 44:602-10. doi: 10.1111/cea.12261

26. Negroni L, Bernard H, Clement G, Chatel JM, Brune P, Frobert Y, et al. Two-site enzyme immunometric assays for determination of native and denatured beta-lactoglobulin. J Immunol Methods. (1998) 220:2537. doi: 10.1016/S0022-1759(98)00150-1

27. Azad T, Ahmed S. Common milk adulteration and their detection techniques. Int J Food Contam. (2016) 3:22. doi: 10.1186/s40550-016-0045-3

28. Chen Q, Ke X, Zhang JS, Lai SY, Fang F, Mo WM, et al. Proteomics method to quantify the percentage of cow, goat, and sheep milks in raw materials for dairy products. J Dairy Sci. (2016) 99:9483-92. doi: 10.3168/jds.2015-10739

29. Nardiello D, Natale A, Palermo C, Quinto M, Centonze D. Milk authenticity by ion-trap proteomics following multi-enzyme digestion. Food Chem. (2018) 244:317-23. doi: 10.1016/j.foodchem.2017.10.052

30. Pizzano R, Nicolai MA, Manzo C, Addeo F. Authentication of dairy products by immunochemical methods: a review. Dairy Sci Technol. (2011) 91:7795. doi: 10.1007/s13594-011-0008-7

31. Rolland MP, Bitri L, Besançon P. Monospecificity of the antibodies to bovine alpha s1-casein fragment 140-149: application to the detection of bovine milk in caprine dairy products. J Dairy Res. (1995) 62:838. doi: $10.1017 /$ S0022029900033690

32. Mohsin AZ, Sukor R, Selamat J, Meor Hussin AS, Ismail IH, Jambari NN, et al. Generation of high affinity anti-peptide polyclonal antibodies recognizing goat $\alpha(\mathrm{s} 1)$-casein. Mol Basel Switz. (2020) 25:2622. doi: $10.3390 /$ molecules 25112622

33. Selvaggi M, Laudadio V, Dario C, Tufarelli V. Major proteins in goat milk: an updated overview on genetic variability. Mol Biol Rep. (2014) 41:103548. doi: 10.1007/s11033-013-2949-9

34. Fox PF. Proteolysis during cheese manufacture and ripening1. J Dairy Sci. (1989) 72:1379-400. doi: 10.3168/jds.S0022-0302(89)79246-8

35. Møller KK, Rattray FP, Høier E, Ardö Y. Manufacture and biochemical characteristics during ripening of Cheddar cheese with variable $\mathrm{NaCl}$ and equal moisture content. Dairy Sci Technol. (2012) 92:515-40. doi: 10.1007/s13594-012-0076-3

36. Trujillo AJ, Guamis B, Carretero C. Proteolysis of goat casein by calf rennet. Int Dairy J. (1997) 7:579-88. doi: 10.1016/S0958-6946(97)00063-0

37. Swaisgood HE. Review and update of casein chemistryl, 2. J Dairy Sci. (1993) 76:3054-61. doi: 10.3168/jds.S0022-0302(93)77645-6

38. Kumosinski TF, Brown EM, Farrell HMJ. Three-dimensional molecular modeling of bovine caseins: an energy-minimized beta-casein structure. $J$ Dairy Sci. (1993) 76:931-45. doi: 10.3168/jds.S0022-0302(93)77420-2

39. Sawyer L, Holt C. The secondary structure of milk proteins and their biological function. J Dairy Sci. (1993) 76:306278. doi: 10.3168/jds.S0022-0302(93)77646-8

40. Morisawa Y, Kitamura A, Ujihara T, Zushi N, Kuzume K, Shimanouchi Y, et al. Effect of heat treatment and enzymatic digestion on the B cell epitopes of cow's milk proteins. Clin Exp Allergy J Br Soc Allergy Clin Immunol. (2009) 39:918-25. doi: 10.1111/j.1365-2222.2009.03203.x

41. Shadur B, Fong A, Altavilla B, Saad RA, Wainstein BK. Skin testing with ultraheat-treated (UHT) cow's milk in children with cow's milk allergy. Ann Allergy Asthma Immunol. (2020) 124:185-9. doi: 10.1016/j.anai.2019.11.010

42. Bloom KA, Huang FR, Bencharitiwong R, Bardina L, Ross A, Sampson HA, et al. Effect of heat treatment on milk and egg proteins allergenicity. Pediatr Allergy Immunol. (2014) 25:740-6. doi: 10.1111/pai.12283

43. Xu Q, Shi J, Yao M, Jiang M, Luo Y. Effects of heat treatment on the antigenicity of four milk proteins in milk protein concentrates. Food Agric Immunol. (2016) 27:401-13. doi: 10.1080/09540105.2015.1117059

44. Viñas $M$, Carnés J, López-Matas MA, Hernández N, Castillo MJ, Ibero M. Allergy to goat and sheep cheese with tolerance to cow's milk and its derivatives. Allergol Immunopathol (Madr). (2014) 42:18690. doi: 10.1016/j.aller.2012.08.002

45. Vélez MA, Bergamini CV, Ramonda MB, Candioti MC, Hynes ER, Perotti MC. Influence of cheese making technologies on plasmin and coagulant associated proteolysis. LWT Food Sci Technol. (2015) 64:2828. doi: 10.1016/j.lwt.2015.05.053 
46. Restani P, Uberti F, Tarantino C, Ballabio C, Gombac F, Bastiani E, et al. Collaborative interlaboratory studies for the validation of ELISA methods for the detection of allergenic fining agents used in wine according to the criteria of OIV resolution 427-2010. Modified by OIV-Comex 502-2012. Food Anal Methods. (2014) 7:706-12. doi: 10.1007/s12161-013-9741-2

47. Holzhauser T, Johnson P, Hindley JP, O'Connor G, Chan C-H, Costa J, et al. Are current analytical methods suitable to verify VITAL $\AA$ 2.0/3.0 allergen reference doses for EU allergens in foods? Food Chem Toxicol Int J Publ Br Ind Biol Res Assoc. (2020) 145:111709. doi: 10.1016/j.fct.2020.111709

Conflict of Interest: The authors declare that the research was conducted in the absence of any commercial or financial relationships that could be construed as a potential conflict of interest.
Publisher's Note: All claims expressed in this article are solely those of the authors and do not necessarily represent those of their affiliated organizations, or those of the publisher, the editors and the reviewers. Any product that may be evaluated in this article, or claim that may be made by its manufacturer, is not guaranteed or endorsed by the publisher.

Copyright $\odot 2021$ Bernard, Hazebrouck, Gaiani and Adel-Patient. This is an openaccess article distributed under the terms of the Creative Commons Attribution License (CC BY). The use, distribution or reproduction in other forums is permitted, provided the original author $(s)$ and the copyright owner(s) are credited and that the original publication in this journal is cited, in accordance with accepted academic practice. No use, distribution or reproduction is permitted which does not comply with these terms. 